\title{
Sixty years of anisotropy of magnetic susceptibility in deformed sedimentary rocks
}

\author{
Josep M. Parés * \\ Geochronology, Research Center for Human Evolution (CENIEH), Burgos, Spain
}

\section{Edited by:}

John William Geissman, University of Texas at Dallas, USA

\section{Reviewed by:}

Eric Font, University of Lisbon, Portugal

Dario Bilardello, University of

Minnesota, USA

\section{${ }^{*}$ Correspondence:}

Josep M. Parés, Geochronology,

Research Center for Human

Evolution (CENIEH), Paseo Sierra de

Atapuerca 3, Burgos 09006, Spain

e-mail: josep.pares@cenieh.es
The use of the Anisotropy of Magnetic Susceptibility (AMS) has become a rather common practice in Earth Sciences since the pioneer note by Graham (1954). The versatility of the technique, and the rapidness in obtaining and processing AMS data largely improved in the past thirty years, and has generated a wealth of literature, notably on mudrock fabrics. The assessment of the current trends in magnetic fabric studies reveals that AMS has one of its largest potential in sedimentary rocks from structural settings where the ductile component of deformation is cryptic or hindered by the brittle component. Abundant evidence provided by AMS data reveal that deformation extents beyond the deformation or cleavage front in contractional settings, including fold-and-thrust belts and active accretionary prisms, configuring magnetic fabrics as a standard method for fabric quantification in deformed sedimentary rocks.

Keywords: magnetic anisotropy, rockfabrics, mudrocks, deformation, preferred grain orientation, accretionary prism, foreland basin

\section{INTRODUCTION}

After John W. Graham proposed 60 years ago, the use of the anisotropy of magnetic susceptibility (AMS) in rocky materials, the subject, with no doubt, has gained an enormous popularity. What Graham referred to as an "unexploited petrofabric element" in 1954, is nowadays an indispensable tool in a wide range of disciplines in Earth Sciences. The study of what we know as AMS in sedimentary rocks begins well before Graham's time nevertheless. Gustav Ising (at the Geophysical Laboratory at Djursholm, Sweden) was interested in varved clays for geomagnetic purposes, i.e., secular variation (Ising, 1942). He had been investigating clay rich sediments since 1926, using first the facility at the Physical Laboratory of the Stockholm University and then the Geophysical Laboratory at Djursholm. Although the aim of Ising's studies was the record of secular variation in varved sediments, he noticed that "the two principal axes (of susceptibility) lying in the horizontal plane posses considerably higher susceptibility values (10-20\%), ... over the vertical susceptibility." From the performed susceptibility measurements obtained, he concluded that the axis of maximum susceptibility is decisive for the "problem of determining the secular variation of the declination from clay measurements."

Graham's seminal paper, 25 years after Ising's work, focused on the application of AMS to deformed sedimentary rocks, where considerable research has shown to have its maximum potential. Indeed he noticed that flat-lying sediments have an oblate magnetic susceptibility ellipsoid, whereas folded sandstones from the Valley and Ridge (Appalachians), have principal axes of maximum susceptibility that are normal to bedding and minimum axes normal to the fold axis of the structures. In the current paper we will further explore the main concept outlined in Graham (1966), namely that magnetic anisotropy in deformed sedimentary rocks is appreciable and that it is related to plastic deformation of sediments very often semiconsolidated.

Shortly after Graham's work, it was well-established that sedimentary rocks acquire a magnetic fabric during deposition (Granar, 1958; Rees, 1961, 1965; Hamilton and Rees, 1971; Kent and Lowrie, 1975) and also that cleaved rocks, slates, have a magnetic fabric that is consistent with the macroscopic foliation (Fuller, 1960, 1963). Although beyond the scope of this paper, the application of AMS to the study of igneous rocks also started soon after to emerge as a powerful fabric tool (Girdler, 1961; Khan, 1962; King, 1966; Heller, 1973; see Bouchez, 1997 and references therein). The AMS studies have been since then employed for purposes as uncommon as characterizing tsunami deposits (Wassmer et al., 2010; Schneider et al., 2014) or for understanding preferred orientation in speleothems (e.g., Zhu et al., 2012).

A remarkable development after Graham's paper is the concept of magnetic carriers that contribute to the magnetic anisotropy. Although what he referred as to "dimensional orientations of ferromagnetic grains" holds true for many rock types, over the years it became apparent that both ferromagnetism and paramagnetism contribute to the total magnetic anisotropy (e.g., Daly, 1967; Parry, 1971), and soon after many scholars emphasized specifically the role of phyllosilicates to the total fabric (Owens and Bamford, 1976; Henry, 1983; Henry and Daly, 1983; Rochette and Vialon, 1984; Borradaile et al., 1986; Lamarche and Rochette, 1987; Borradaile, 1988). Because phyllosilicates (most abundant paramagnetic minerals in sedimentary rocks) occur as platy grains whereas magnetite typically as euhedral, they will behave differently upon stress and therefore is critical to separately characterize their preferred orientation and degree of alignment. Also, in sedimentary rocks, phyllosilicate minerals often represent a larger volume fraction than ferromagnetic (accessory) minerals 
and therefore are likely to yield more accurate and representative fabric information. After the pioneering studies by Daly (1967) and Parry (1971), a number of scholars became interested and developed methods aimed at fabric separation (Owens and Bamford, 1976; Henry, 1983; Rochette and Fillion, 1988, and more recent Bilardello and Jackson, 2014). The rationale for such separation of magnetic anisotropies is based on the variation of susceptibility with either temperature or applied field. Basically there are two different approaches, namely tensor subtraction and instrumental isolation of the paramagnetic anisotropy (see Martín-Fernández and Ferré, 2007 for a comprehensive review). Here follows a summary of the methods.

Scriba and Heller (1978) and Schmidt et al. (1988) used a $100 \mu \mathrm{T}$ radial field in a SQUID magnetometer and rotated the sample about each of three mutually perpendicular axes in steps of $45^{\circ}$, for a total of 24 positions, to determine the anisotropy tensor. Rochette and Fillion (1988) used a vertical-access SQUID magnetometer and trapped a DC field. By rotating the sample about a horizontal axis at a frequency of $0.01 \mathrm{~Hz}$ and analyzing the generated signal, they determined the susceptibility anisotropy of both ferromagnetic and paramagnetic fractions.

The principle of a vibrating sample magnetometer (VSM) is based on the flux change in the pick-up coil system produced by a sample that is vibrating (rather than by rotation, as in spinner magnetometers). There have been several studies using a VSM to obtain directional hysteresis curves for different positions of the specimen, and hence enabling to the calculation of a High Field AMS (Thill et al., 2000; Kelso et al., 2002; Ferré et al., 2004).

The torque magnetometer is possibly the most popular instrument to measure high field magnetic susceptibility (Banerjee and Stacey, 1967; Owens and Bamford, 1976; Ellwood, 1978; Parma, 1988; Borradaile and Werner, 1994). The basic principle is the measurement of torque exerted on a sample by an applied magnetic field due to the anisotropy of the sample as it is rotated to different azimuths about an axis perpendicular to the field. The torque $T$ is given by $T=\mathrm{dE} / \mathrm{d} \theta$, where $E$ is the energy of magnetization of the sample and $\theta$ is the direction of the applied field. It is thus possible to estimate the anisotropy present in the rock from a Fourier analysis of the torque curve. Hrouda and Jelinek (1990) presented a mathematical method for separating the components by measuring a sample in two different fields above the saturation magnetization of the ferromagnetic contribution. More recently, Martín-Hernández and Hirt (2001) presented a mathematical method that utilizes measurements in several high fields toward separating the ferromagnetic and paramagnetic components of the magnetic fabric. By using a larger number of fields, instead of two as described by Lowrie (1989), a more accurate definition of the paramagnetic susceptibility tensor can be obtained.

\section{SOURCE OF MAGNETIC SUSCEPTIBILITY}

Most studies that followed Graham's (1954) work focused on sedimentary rocks, including sandstones and mudstones. Although in Graham's view, the magnetic fabric obeys "dimensional orientations of the ferromagnetic grains" we now know that the paramagnetic contribution is usually more significant that the former in these rocks (see Tarling and Hrouda, 1993 and references therein). To illustrate this issue of ferromagnetism vs. paramagnetism in sedimentary rocks, we need to look at the rock composition and constituents. Sandstones are sedimentary rocks consisting of detrital sand-sized grains, that form the framework of the sediment, fine-grained matrix between the grains, and authigenic minerals. The most common detrital mineral in sandstone is quartz, on average $65 \%$ although some sandstones are made of practically $100 \%$ quartz. Feldspar content averages between 10 and $15 \%$, except in arkoses where it reaches $50 \%$. The remaining minerals typically include phyllosilicate minerals (biotite, muscovite, chlorite, kaolinite, smectite, illite), and heavy minerals (zircon, rutile, amphiboles, hematite, magnetite, etc.). Mudstones - a mixture of clay and silt sized particlesconstitute some $45-55 \%$ of sedimentary rock sequences. Shale is a laminated and fissile mudrock, as opposed to the blocky, non-fissile mudstones. By definition the main constituents of mudrocks are clay minerals ( $42 \%$ on average) and silt-grade quartz (38\%). Other minerals (less than 5\%) include feldspar, calcite, plagioclase pyrite, etc. Whereas ferromagnetic (sensu lato), moderate to high susceptibility minerals (e.g. magnetite, hematite) are minor components, the dominant mineralogy corresponds to paramagnetic, lower magnetic susceptibility phases. Indeed, the average value of bulk magnetic susceptibility of mudrocks $\left(10^{-4}\right.$ to $\left.10^{-5} \mathrm{SI}\right)$ suggests that the concentration of iron oxides such as magnetite is typically less than $0.01 \mathrm{wt} \%$ (Figure 1) which is consistent with the dominance of paramagnetic susceptibility in mudrocks. Numerous rock-magnetic studies where paramagnetic and ferromagnetic susceptibilities have been quantified revealed that typically the former dominates in mudstones (e.g., Martín-Hernández and Hirt, 2001 and references therein), therefore the AMS is dominated by the paramagnetic component, and most specifically by the shape anisotropy of clay minerals although very fine magnetic particles attached to the clay fabric might also contribute (Kodama and Sun, 1992).

Although there is agreement in that AMS in pelitic rocks is typically controlled by paramagnetic phyllosilicate minerals, errors might arise when such very fine magnetic particles, specifically single domain (SD) magnetite, are present in large quantities. The magnetic anisotropy of magnetite is determined by its magnetic grain size (Stephenson et al., 1986). For multidomain (MD) particles, the maximum/minimum susceptibility coincides with the long/short axes of the grains, and therefore the bulk magnetic fabric mimics grain orientation. However, in SD particles the minimum axis of susceptibility is parallel to the long axes of the grain, producing an "inverse magnetic anisotropy" (Jackson, 1991). The term "inverse magnetic fabrics" was originally coined by Rochette and Fillion (1988), who actually sought two causative models: (1) c-axis preferred orientation of ferroan calcite grains whose maximum susceptibility is parallel to the c-axis, and (2) single-domain elongated magnetite grains. In mudrocks, the former is rather uncommon due to the very low concentration of calcite. Several authors have observed "inverse fabrics" in Fe-calcite rich rocks (Ihmlé et al., 1989; Hirt and Gehring, 1991; de Wall et al., 2000; Hounslow, 2001). However, because unusually high proportions of SD magnetite would be required, few rocks show a net inverse magnetic fabric due to magnetite (Borradaile and Jackson, 2004). The inverse fabric, i.e., SD-related inverse fabric, 


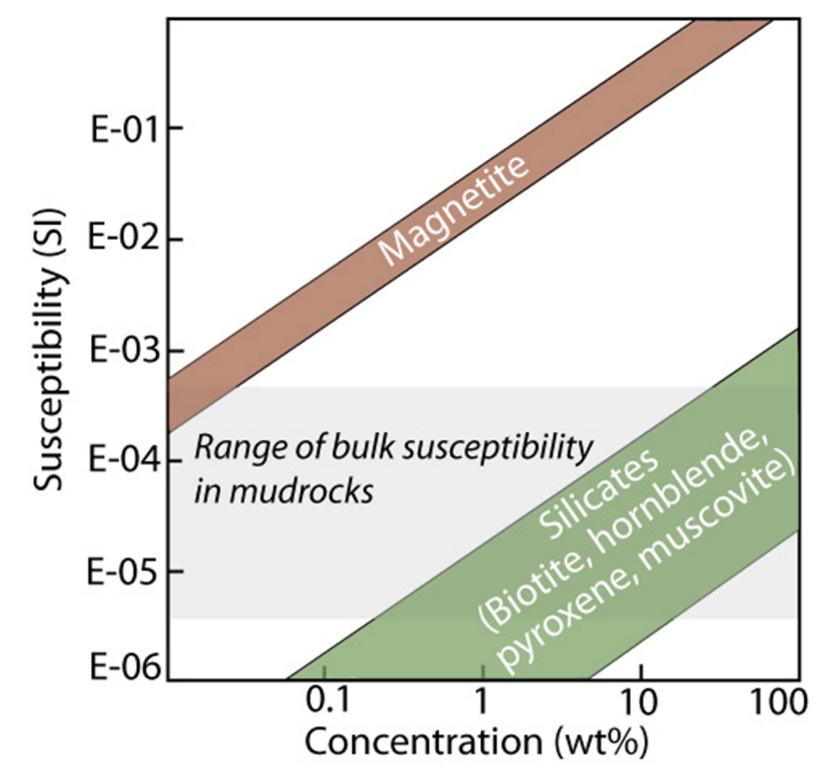

FIGURE 1 | Bulk susceptibility and mineral contribution. The total susceptibility in a given rock will depend on both the intrinsic susceptibility and the concentration of the individual minerals. Magnetite (ferromagnetic) and some common rock-forming silicates have been shown as a reference. The gray, horizontal bar shows the susceptibility range for most mudrocks, revealing that the contribution by paramagnetic grains (in particular phyllosilicate) is larger than magnetite.

is otherwise rather common in igneous rocks (e.g., Borradaile and Gauthier, 2001; Zhang et al., 2011).

The topic of inverse fabric related to SD magnetite is explored in Jackson (1991), and as of today it is still a poorly resolved topic (e.g., Tarling and Hrouda, 1993). Determining whether SDmagnetite is producing inverse fabric requires methods that can isolate different magnetic grain size of magnetite, which include measurements such as the anisotropy of anhysteretic remanent magnetization (AARM) (Jackson, 1991). Some theoretical models for inverse magnetic fabrics have also been developed (e.g., Ferré, 2002).

\section{ANISOTROPY OF MAGNETIC SUSCEPTIBILITY (AMS)}

The low field magnetic susceptibility of a rock (the ratio of magnetization to the applied field or $K=\mathrm{M} / \mathrm{H}$ ) is given by the total contribution of its bulk mineralogy, including paramagnetic (e.g., phyllosilicates, iron-bearing feldspars), diamagnetic (e.g., quartz, calcite) and ferromagnetic (sensu lato; e.g., magnetite, goethite, hematite) grains. An intrinsic property of most of these rock-forming minerals is that their magnetic susceptibility is anisotropic (Nye, 1957) and thus $K_{i j}=\mathrm{M}_{i} / \mathrm{H}_{j}$. For example, it has been demonstrated that magnetic axes in biotite crystals conform to the density distributions of mineral lattice planes obtained by x-ray goniometry (Richter et al., 1993; Schmidt et al., 2009) (Figure 2). These results reveal that densities from $x$-ray for chlorite and mica are perfectly reflected by the distribution of the minimum susceptibility axes. The study by Richter et al. (1993) was possibly the first demonstration that the normalized magnetic parameters $\left(\mathrm{M}_{\mathrm{i}}=\ln \left(\mathrm{k}_{\mathrm{i}} /[\mathrm{kmax} * \mathrm{kint} * \mathrm{Kmin}]^{1 / 3}\right)\right.$
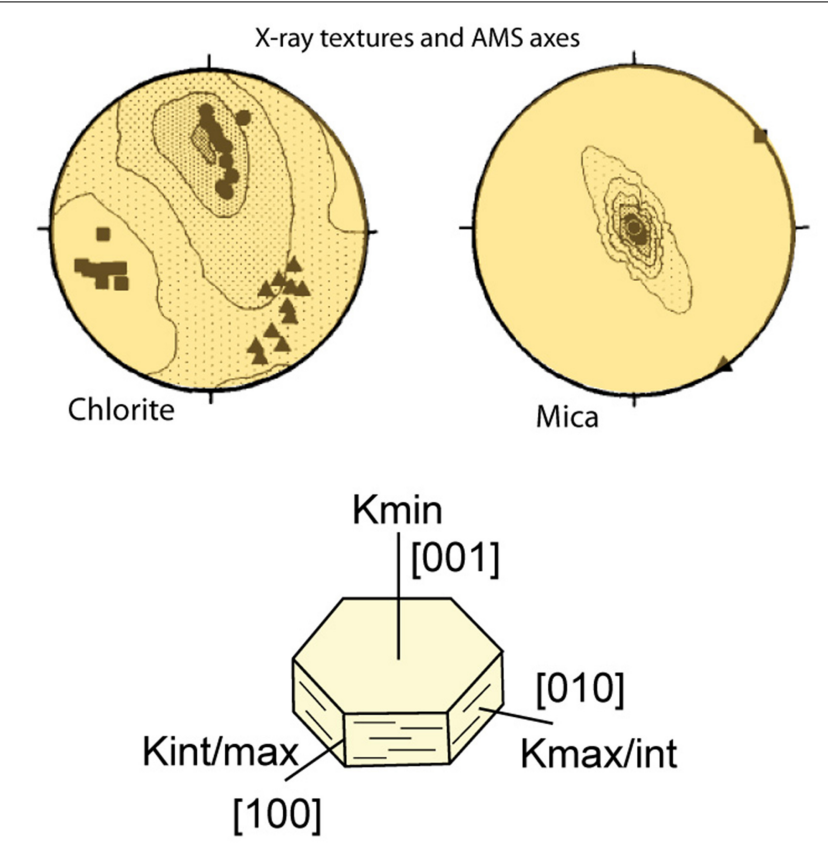

FIGURE 2 | Stereoplots for chlorite and mica dominated specimens, comparing the $x$-ray texture data (shaded regions) and the orientation of the principal axes of magnetic susceptibility (squares $=K_{\max }$, triangles $=\mathbf{K}_{\mathbf{i n t}}$, dots $=\mathbf{K}_{\mathbf{m i n}}$ ) ( modified from Richter et al., 1993). The minimum susceptibility axes show perfect agreement with the maximum density of the chlorite and mica basal plane.

correlate directly with March strains as obtained from x-ray texture goniometry. The study was an important step forward showing the AMS as a sensitive and rapid gage for bulk crystallographic preferred orientation in rocks, with the advantage of using large sample volumes (typically about $11 \mathrm{~cm}^{3}$ ), as opposed to the essentially two-dimensional slice used in optical and X-ray methods (Figure 2). Later studies by Borradaile and Werner (1994), Martín-Hernández and Hirt (2003), and Biedermann et al. (2014) have provided more details on the magnetic anisotropy of single silicate crystals.

AMS defines a symmetric, second-rank tensor that has six independent matrix elements. When the coordinate system is referred to the eigenvectors, these trace an ellipsoid that is known as the magnitude ellipsoid (Nye, 1957) whose semi-axes are the three principal susceptibilities $\left(\mathrm{K}_{\max }>\mathrm{K}_{\text {int }}>\mathrm{K}_{\min }\right)$. In sedimentary rocks, AMS depends mostly on the crystallographic preferred orientation of the individual components, compositional layering, distribution and size of microfractures, and the shape fabric of grains. The AMS tensor tracks preferred orientation and consequently its applications embrace a wide range of disciplines in Geosciences, and notably in structural geology (e.g., Housen et al., 1993; Borradaile and Henry, 1997; Martín-Hernández et al., 2004; Borradaile and Jackson, 2010 and references therein).

\section{SEDIMENTARY MAGNETIC FABRIC}

Sediments acquire and develop a magnetic fabric throughout a long and complex process. The term fabric for sedimentary rocks involves the grains orientation and packing, and the nature of the 
boundaries between grains. Clay particles in muds tend to have positively charged edges and negatively charged faces (Langston and Pask, 1958), which will cause small flocs of edge to face (EF) particles in the earliest stages of deposition (Bennett et al., 1991). The peds are often electrostatically connected by longchained clay platelets interconnected by high angle EF contacts (e.g., Kawamura and Ogawa, 2002, 2004). The porosity between these peds is relatively large $(10 \mu \mathrm{m})$. During progressive consolidation as overburden pressure increases, the clay platelets collapse developing face to face (FF) contacts and the porosity is reduced (Figure 3). The collapse of the clay structure during burial results in a volume decrease by diminishing macropores. Hence, the normal progressive consolidation and burial of clay-rich sediments results in a downsection decrease in porosity. This progressive clay fabric change during burial determines to large extent the magnetic properties, which many scholars have studied throughout AMS (Housen et al., 1996; Kopf and Berhman, 1997; Kawamura and Ogawa, 2002, 2004; Schwehr et al., 2006) (Figure 3C).

From the abundant AMS data, it is apparent that the pattern evolution of sediments depositing has a strong imprint on the AMS. For burial depths of several centimeters, EF contacts and long chains of clay flakes dominate the clay fabric, which results in a certain degree of magnetic lineation. The underlying reason is the "magnetic zone axis" (Henry, 1997), which is expressed as a magnetic lineation and thus ellipsoids are typically prolate. At depths of several meters clay flakes rotate from EF to FF contacts, shortening the connectors (Kawamura and
Ogawa, 2004), and hence there is an increase in both the magnetic foliation and the anisotropy degree (Figure 3C). Although several studies suggested that several hundred meters are required to develop a horizontally preferred orientation in muds (e.g., Moon and Hurst, 1984; Bennett et al., 1991; Kawamura and Ogawa, 2004), recent magnetic studies show that a horizontal anisotropy develops much earlier on in the sedimentary column (Taira and Niitsuma, 1986; Kanamatsu and Matsuo, 2003; Ujiie et al., 2003a; Kanamatsu et al., 2012; Novak et al., 2014).

Upon progressive increase in overburden, and as clay fabric changes from EF to FF, magnetic ellipsoids will tend to become oblate and the anisotropy degree (P) will increase with depth as porosity decreases and packing increases (Figure 4). An exception would be when sediments are in a state of overconsolidation. Overpressured sediments form under many circumstances, such as under high sediment accumulation rates, mineral dehydration, gas liberation, and low permeability. As a result, pore fluid escape is inhibited and it has to temporarily sustain the entire stress acting on the sediment. Sediments become overpressurized in such high water content zones. Among other effects, such zones of high water content prevent the EF contacts from changing to FF contacts (Schwehr et al., 2006). More importantly, as will be discussed below, overpressure weakens the sediments (e.g., Maltman, 1994), which facilitates grain sliding. The fluid between pores sustains part of the burial stress, which reduces friction and hence sediment strength. Overpressured zones are potential sites for shear and therefore are critical for sediment deformation.
A

Single plate and chains

(Edge-to-face contacts)

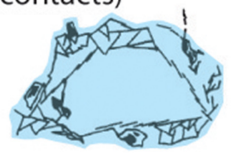

Domain particles

and chains

(EF dominate)

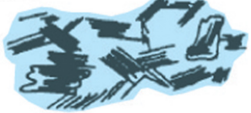

Dominance of face-to-face contacts
B

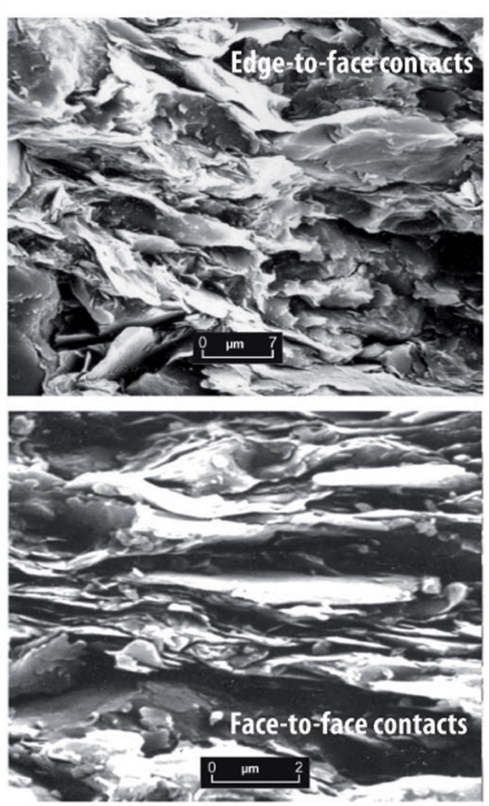

C

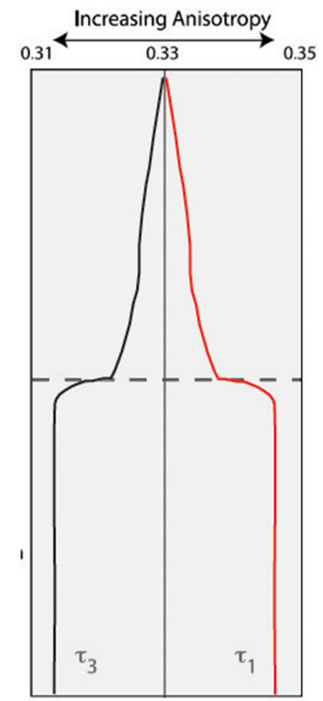

FIGURE 3 | Progressive change of clay microstructure during burial process. (A) The contact between particles changes from high-angle EF (edge-to-face) to low-angle EF and FF contact compaction. Particles slide and rotate normal to the maximum stress direction (modified from Bennett et al., 1991). (B) Example of mudstone compaction fabrics. Photo on top shows a weakly oriented clay assemblage, with open pore structure dominated by EF contacts. The example below shows a more oriented clay population, with as classic FF contact distribution (modified from Wilson and Wilson, 2014). (C) Conceptual model of degree of anisotropy evolution with burial. As compaction progresses, the overall anisotropy of susceptibility increases shown as the minimum and maximum eigenvalues of the susceptibility tensor (modified from Schwehr et al., 2006). 


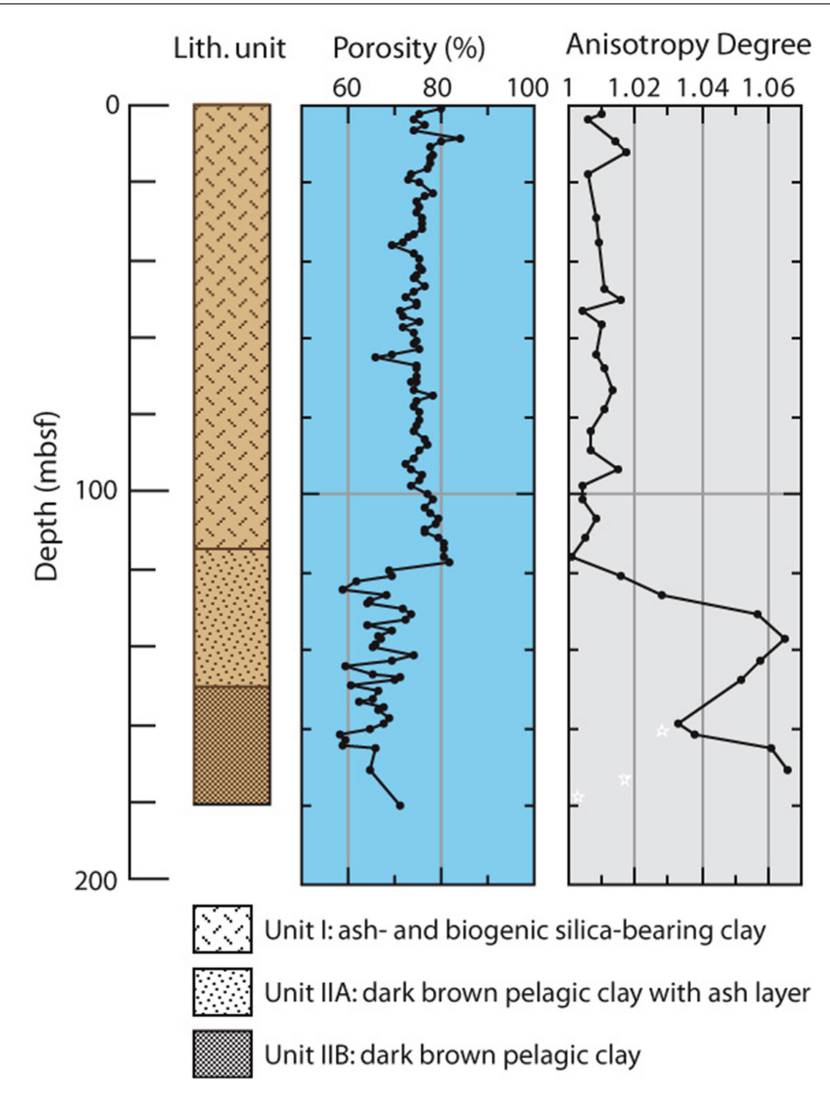

FIGURE 4 | Changes of porosity and anisotropy degree (P) with depth (IODP Hole 1149A) (modified from Kawamura and Ogawa, 2002).

Underconsolidated layers have been detected via AMS (e.g., Schwehr et al., 2006) revealing a new approach to detect compaction disequilibrium in marine environments. Such layers are characterized by a reduced magnetic anisotropy, as compared to what would be expected in a standard consolidation profile.

\section{MAGNETIC ANISOTROPY AND WEAK DEFORMATION}

Since the seminal paper by Graham (1966) where he pointed out that AMS in sediments indicate "the final shape distortions," many scholars have exploited the property in order to retrieve the strain imprint in sedimentary rocks, particularly in the weak deformation realm. In the late seventies and through the eighties, and possibly due to the development of improved measuring techniques (Molyneux, 1971; Jelinek, 1973; Rathore, 1975) rock magnetic anisotropy studies intensified, and specifically in shales and slates (Hrouda and Janak, 1976; Kligfield et al., 1977, 1981; Rathore, 1980; Turner and Gough, 1983; Rochette and Vialon, 1984; Hirt et al., 1988 among others). In anchimetamorphic grade rocks, AMS has been shown to have a great potential to track early deformation stages (Hirt et al., 1995, 2000, 2004; Robion et al., 1995, 1997, 1999; Lüneburg et al., 1999; Gil-Imaz et al., 2000; Parés and van der Pluijm, 2003; Debacker et al., 2004). Although Borradaile and Tarling (1981) reported results from "weakly deformed slates," the study by Kissel et al. (1986) is possibly the first to demonstrate the great potential of AMS, as these authors showed that by using this technique it is possible to detect very subtle deformation in rocks otherwise considered to be undeformed. More recent contributions by Aubourg et al. (1991), Averbuch et al. (1992), Owens (1993), Parés and Dinarès (1993), Sagnotti and Speranza (1993), Collombat et al. (1995), Parés et al. (1999), Sagnotti et al. (1999) (also see Borradaile and Jackson, 2004 for a review) take advantage of the sensitivity of AMS to identify and define the orientation of weak tectonic magnetic fabrics arising from phyllosilicate minerals. In most of these examples, the studied mudrocks are uncleaved, typically flat-lying, and macroscopically undeformed. Despite the field appearance of these mudrocks, a subtle, weak tectonic fabric is observed due to the AMS features. In an effort to merge all these models for fabric development arising from tectonic deformation with magnetic fabrics, Parés et al. (1999) proposed a model for progressive stages in AMS evolution in strained mudrocks. The model includes four type of magnetic fabrics that develop in weakly deformed mudrocks undergoing progressive deformation and has subsequently been observed and adopted in later studies of similar rock types (Figure 5) (Frizon de Lamotte et al., 2002; Saint-Bezar et al., 2002; Souqué et al., 2002; Sans et al., 2003; Larrasoaña et al., 2004; Parés, 2004; Robion et al., 2007; Cifelli et al., 2009; Debacker et al., 2009; Oliva et al., 2009; Soto et al., 2009; Weil and Yonkee, 2009; Mochales et al., 2010; Pueyo-Anchuela et al., 2010). A common feature in most of these studies is the realization that AMS records preferred grain orientation in sedimentary rocks with no macroscopic strain indicators, even before the appearance of embryonic cleavage (Ramsay and Huber, 1983). The deformation pathway represented in Figure $\mathbf{5}$ summarizes the magnetic fabric path of mudrocks under progressive deformation (layer parallel shortening).

A summary of the AMS studies developed in deformed mudrocks is as follows:

(1) Principal axes of maximum susceptibility $\left(\mathrm{K}_{\max }\right)$ are particularly sensitive to tectonic shortening, as they develop a magnetic lineation that mimics the intersection of bedding and tectonic flattening plane (the strain XY plane).

(2) Layer parallel shortening extends well-beyond the "deformation front" in orogenic settings.

(3) An intermediate fabric (Types IIa and IIb) is very common where bedding and flattening planes compete to identify the finite magnetic anisotropy ellipsoid.

\section{AMS DATA FROM ACTIVE ACCRETIONARY PRISMS SEDIMENTS}

Accretionary prims closely resemble fold-and-thrusts belts exposed onshore, and therefore constitute a natural laboratory to better understand the mechanical behavior of shortening in the crust. The process of accretion is a preliminary process in mountain building and hence in continental growth. With the advent of ocean deep drilling since the mid 1960's (DSSP, ODP, and IODP), thousands of meters of sediment from many accretionary prisms were made available for studying several geologic and geophysic properties, including AMS, after several decades of drilling in Barbados, Costa Rica, and Nankai accretionary prisms. Because large volume of sediments in accretionary prims have never been exhumed, and they are under active shortening, we can measure 


\section{AMS axes evolution in mudrocks under stress}

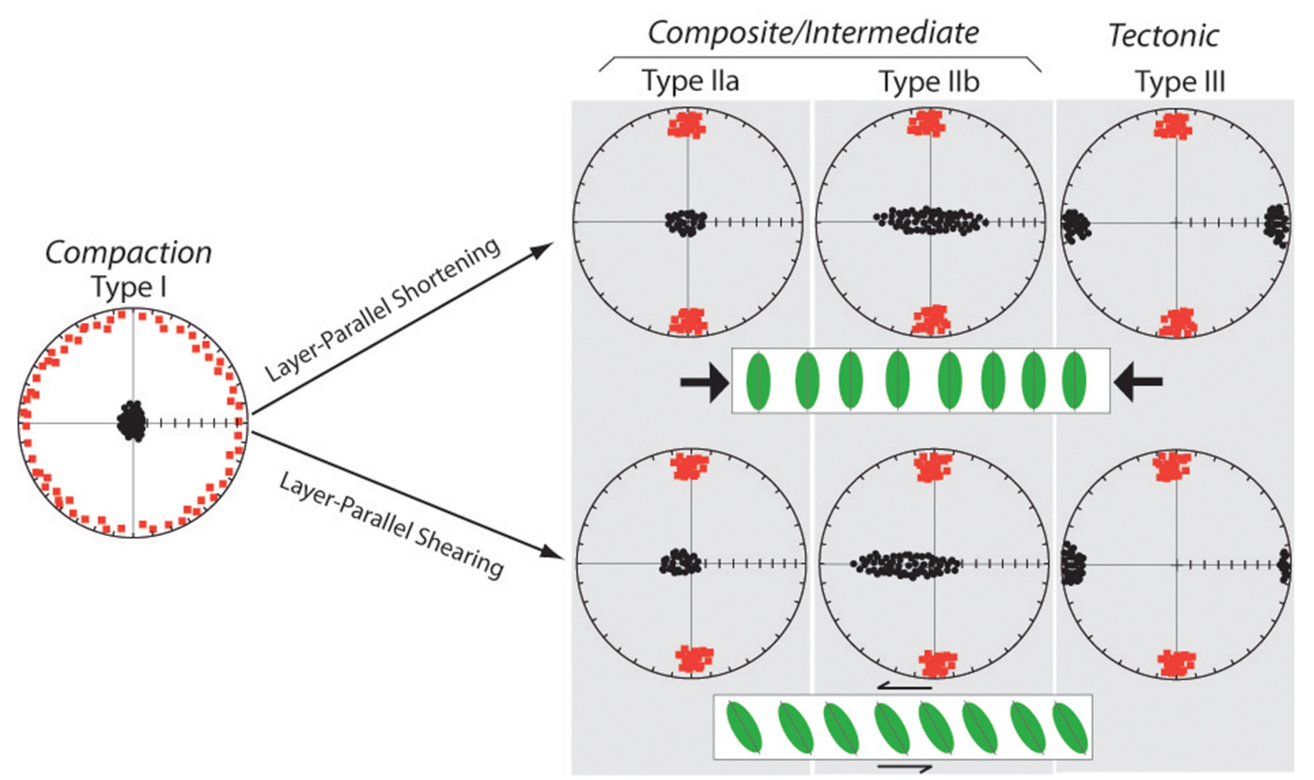

FIGURE 5 | Conceptual model of AMS development in mudrocks undergoing progressive deformation. Type I fabric is essentially a compaction, sedimentary fabric with $\mathrm{K}_{\min }$ axes normal to the deposition plane and $K_{\max }$ axes scatter along it. Type $\|$ (a and b) fabric reveals the imprint of the first lateral shortening on the initial sedimentary fabric where both LPS (layer parallel shortening) (or shearing) plane and depositional plane compete to define the total magnetic fabric. $K_{\max }$ axes parallel the intersection direction between these two planes. $K_{\min }$ axes eventually show a girdle that is parallel to the maximum shortening direction. Ultimately $\mathrm{K}_{\min }$ axes become parallel to the shortening direction and $K_{\max }$ axes remain parallel to the intersection direction and not necessarily to the maximum extension direction. Rocks deformed by layer-parallel shearing, Types $\mathrm{Ila}$ and IIb ellipsoids show a girdle of $\mathrm{K}_{\text {min }}$ axes that are plunging away from the tectonic extension direction. physical properties that are otherwise unavailable in uplifted and exhumed fold-and-thrust belts.

We will discuss results from the Nankai accretionary prism (Figure 6), although more data are available by Hounslow (1990), Housen et al. (1996); Housen (1997) as far as the Barbados accretionary prism, and by Housen and Sato (1995) and Owens (1995) for the Cascadia. The Nankai trough marks the boundary between Eurasia and the Philippine Sea Plate along southwest Japan, and has been the site of deep drilling since DSDP Leg 31 in 1991. Although Legs 56 and 57 were drilled in the forearc of the Japan Trench, no magnetic anisotropy data are available for the recovered cores. During Leg 31, Site 298 was drilled into the toe of the accretionary prism, but unfortunately core recovery was too poor for any meaningful study.

Taira and Niitsuma (1986) reported the first rock-magnetic data including AMS in sediments from the active accretionary prism in SW Japan, along the Ashizuri transect. Two sites from Leg 87 were studied, 583 and 582, which come from near the frontal thrust and ahead of the deformation front, respectively (Figure 7). Site 582, at about $7 \mathrm{~km}$ ahead (seawards) of the frontal thrust, was sampled for AMS between depths 66 to about 750 mbsf (meters below sea floor), including Quaternary turbidites and Pliocene hemipelagic muds. Site 583, behind the frontal thrust, was sampled to a depth of $442 \mathrm{~m}$. Because the ages of the sediments are known and hence the reference paleomagnetic direction, samples for AMS analysis were re-oriented using remanence data and therefore the principal axes of susceptibility for these two sites could be referred to geographic coordinates. In this earliest study in the Ashizuri transect, the AMS data already show a pattern that later on is observed not only in acretionary prisms but also in their onshore analogs, foreland basins ahead of foldand-thrust belts. Site 582, farther away from the frontal thrust, reveals a predominance of sub-vertical $\mathrm{K}_{\min }$ axes and a scatter, in the horizontal plane, of $K_{\max }$ axes (Figure 7). In contrast, Site 583, just NW of the frontal thrust, reveals a slightly NW-SE elongated dispersion of $\mathrm{K}_{\min }$ axes while $\mathrm{K}_{\max }$ have dominantly a NE-SW direction. In their study, Taira and Niitsuma (1986) interpret the $\mathrm{K}_{\max }$ grouping to be related to a NE-SW paleocurrent, so axial to the main trend of the trough. A possible alternative explanation for the distribution of $K_{\min }$ axes at Site 583 is a NW-SE tectonic shortening (as already pointed out by Taira and Niitsuma, 1986). The fact that ellipsoids at Site 583 are dominantly prolate would support that interpretation.

Along the second large transect targeted by the ODP and IODP programs is the so-called "Muroto transect" (Figure 6), which runs from the Shikoku Basin, in the NE and ahead of the frontal thrust zone, to the accreted sediments, landwarddipping zone (Moore et al., 2001), encompassing over $80 \mathrm{~km}$ from the SW to the NE. Unfortunately, only a few sites have been analyzed for AMS (including Site 808, next to the protothrust zone, and Site 1178, well in to the overthrusting plate). ODP Leg 131 (Site 808) was a milestone in the study of active accretionary prisms, as it recovered more than $1000 \mathrm{~m}$ of hemipelagic silt and clay, across the basal décollement of the Nankai Trough 


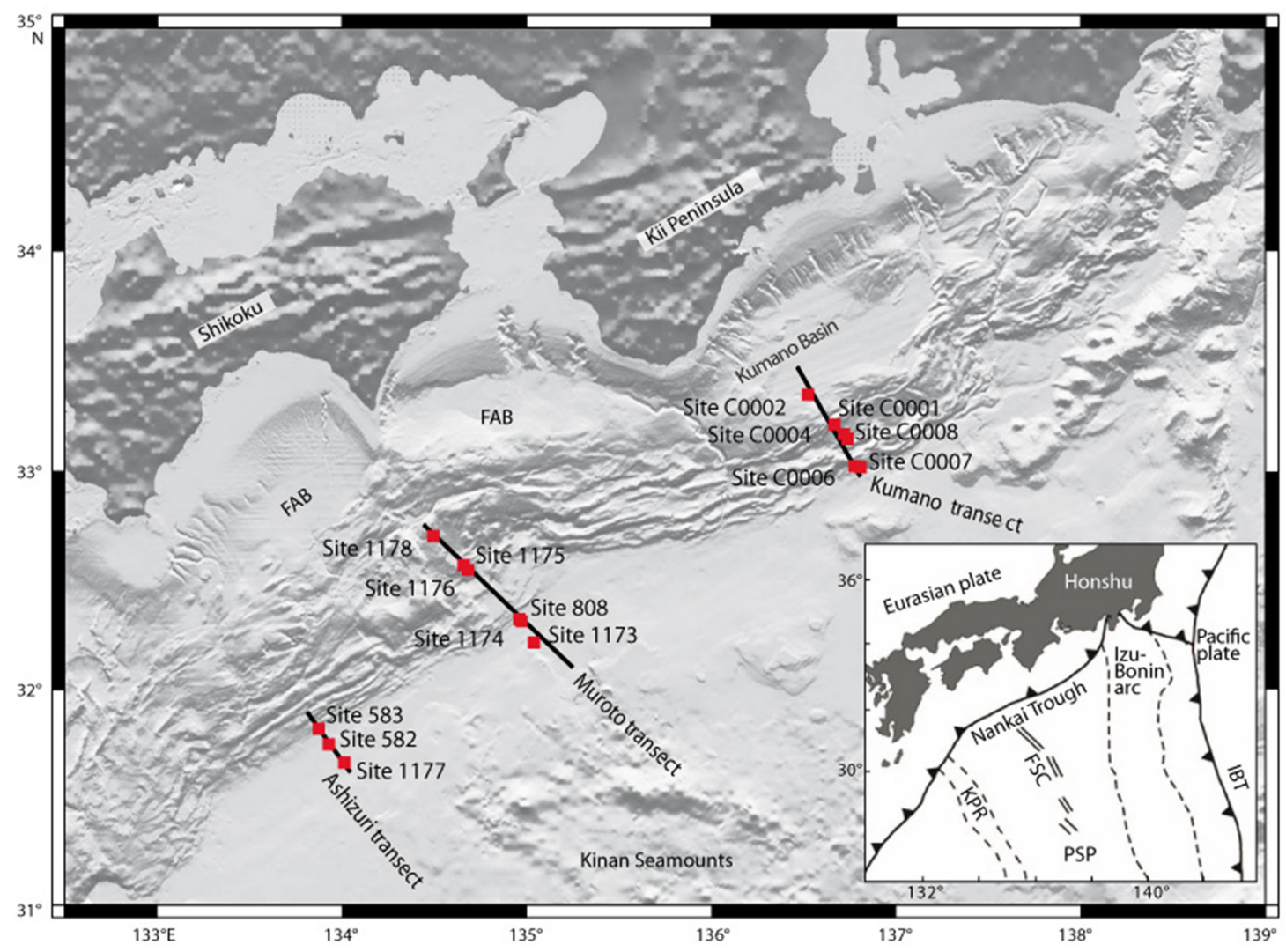

FIGURE 6 | Regional setting o northern Shikoku Basin and Nankai Trough region showing existing DSDP, ODP and IODP drilling transects. $F A B$, forearc basin; Inset, tectonic map showing plate tectonic setting of the region; IBT, Izu-Bonin Trench; KPR, Kyushu-Palau Ridge; FSC, fossil spreading center; PSP, Philippine Sea plate (Moore et al., 2009)

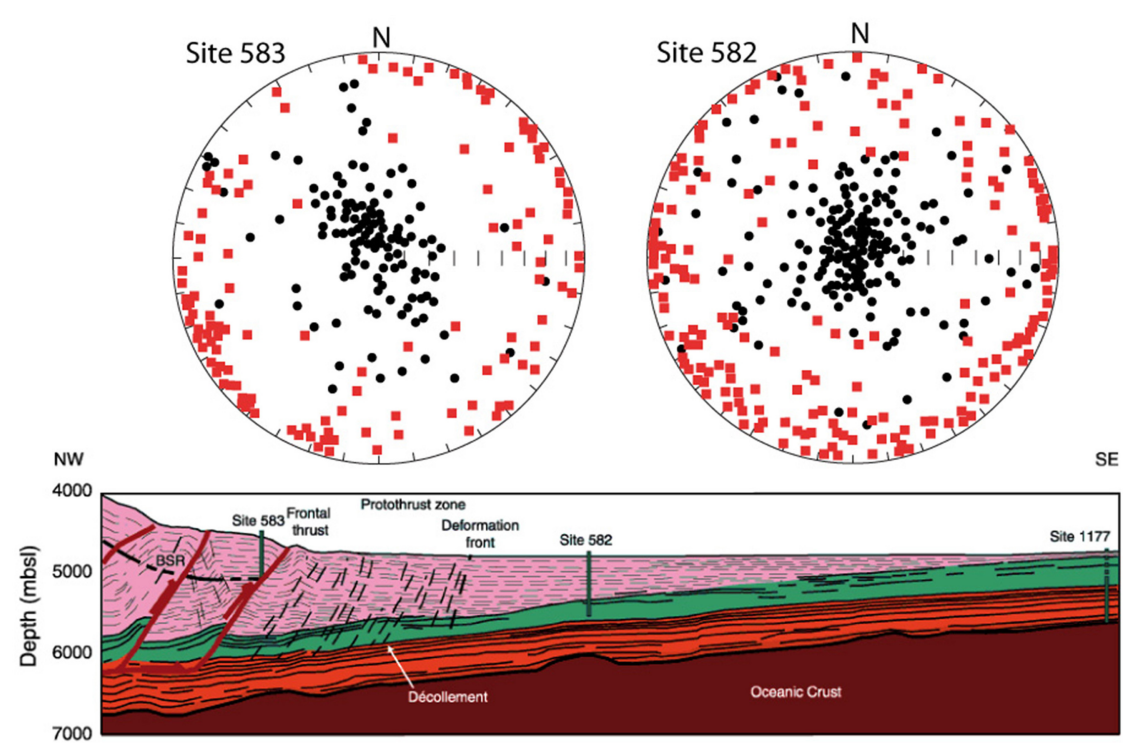

FIGURE 7 | AMS axes for two DSDP sites in the Ashizuri transect (Nankai Trough). Lower-hemisphere, equal-area projection of the $K_{\max }$ (red squares) and $K_{\min }$ (black dots) principal axes of susceptibility for
Sites 583 and 582 (re-drawn from Taira and Niitsuma, 1986). Cross section shows the structural position of the two drill sites along the transect. 
subduction zone. The AMS study by Owens (1993) possibly allows for the first time to observe the changes in magnetic fabrics above and below a décollement in an accretionary prism. The samples from below the décollement, covering a depth range of 950-1050 mbsf, once oriented (using paleomagnetic directions), reveal a typical depositional fabric, including vertical $K_{\min }$ axes and scattered $K_{\max }$ axes within the depositional plane (Figure 8). The magnetic ellipsoid is strongly oblate, consistent with a sedimentary fabric. Above the décollement, between 400 and $935 \mathrm{mbsf}$, the magnetic ellipsoid moves toward the prolate field and the axes distribution resembles that of a tectonically deformed flatlying sedimentary rock, i.e., subvertical $\mathrm{K}_{\min }$ axes and a SW-NE clustered $\mathrm{K}_{\max }$ axes, so normal to the local shortening direction (NW-SE). Later AMS studies of Site 1174 (Ujiie et al., 2003b), just farther SE, produce very similar patterns to Site 808C.
The NW part of the Muroto transect includes a locality on the accreted sediments, which makes possible contrasting the fabrics of sediments from the overthrusting plate away from the subduction zone. Site 1178, Leg 190/196, is a good example (Ujiie et al., 2003a,b). The magnetic fabrics obtained in Site 1178, which encompass a thickness of around $450 \mathrm{~m}$, reveal features that the previous transect does not show. A total of 147 oriented samples show that the $\mathrm{K}_{\min }$ axes are dominantly SE dipping, whereas $\mathrm{K}_{\max }$ axes yield a slight NE-SW magnetic lineation trend (Figure 8). Because bedding can be determined using paleomagnetic data, Site 1178 offers a unique view of the internal fabric in accreted sediments within the prism. The SE plunging $K_{\min }$ axes are consistent with a top to the SE shearing, as expected in the subduction zone. Ujiie et al. (2003a) interpreted the AMS data as S-C fabrics, related to the initial strain development at the frontal part of the prism.

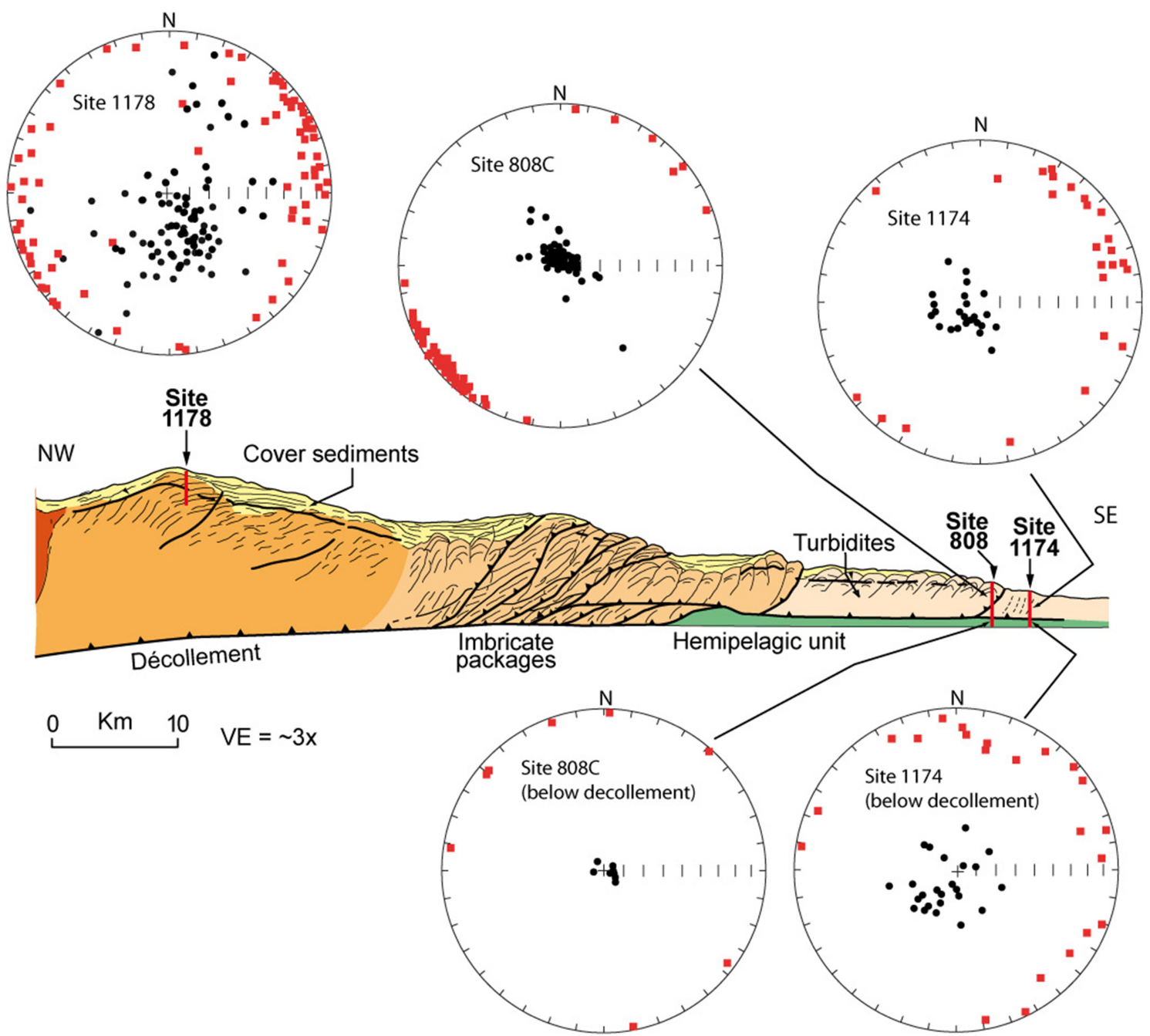

FIGURE 8 | AMS from selected ODP and IODP sites along the Muroto transect (Nankai Trough) (cross section modified from Moore et al., 2001). Lower-hemisphere, equal-area projection of the $K_{\max }$ (red squares) and $K_{\min }$ (black dots) principal axes of susceptibility for Sites 1178, 808C, and 1174 (re-drawn from (Ujiie et al., 2003a,b), and (Owens, 1993), respectively). For sites 808C and 1174, we have represented the AMS axes from above and below de décollement. 
A corollary of the AMS studies in accretionary prisms is that layer parallel shortening is recorded in unlithified mudrocks at very shallow depths, a question that probably has not been yet studied in detail.

\section{MECHANISMS OF PREFERRED ORIENTATION DEVELOPMENT}

AMS data from mudrocks open the question of the origin of tectonic magnetic fabric in such rocks, including whether is domainal or penetrative, and ultimately the mechanism for grain preferred orientation. In rocks with discrete cleavage surfaces (by pressure-solution), Borradaile and Tarling (1981) showed that the AMS axes orientation results from the interference between such planes and the original sedimentary fabric. Anisotropy in such rocks is characterized by ellipsoids with $\mathrm{K}_{\max }$ axes that follow the cleavage-bedding intersection, essentially Type IIa or IIb magnetic ellipsoids (Parés et al., 1999), and so not parallel to the $\mathrm{X}$-direction (maximum extension) of the strain ellipsoid (Parés and van der Pluijm, 2002).

Many tectonic microstructures including kink bands, cleavage steps, and biotite fish, which would have a profound impact on the magnetic fabric, are known to form in shales and slates. Folding and intragranular kinking in mica grains is a rather common process in very low grade rocks (e.g., Van der Pluijm and Kaars-Sijpesteijn, 1984). Kanaori et al. (1991) reported mica kink bands and cleavage steps in granites, and Goswami and Sarmah (2013) also observed kinking in the sandstones from the Siwalik belt in the western and Central Himalayas. In both cases, rocks are found in cataclasites, formed under higher P-T conditions. In an AMS study of the Sevier fold and thrust belt, Weil and Yonkee (2009) reported kinked mica grains in Triassic redbeds, which would explain the magnetic fabric in the redbeds. However, biotite typically requires temperatures above $250^{\circ} \mathrm{C}$ to behave ductilely and develop microstructures such as kinking (e.g., Stesky, 1978). Such temperatures are seemingly too high for the deformation realm that we are discussing in this paper. It seems, therefore, that the process of kinking cannot account for the tectonic fabric observed in mudrocks due to the lower temperatures where deformation takes place.

Studies of mudrocks obtained in DSDP Sites 583 (Lundberg and Karig, 1986), ODP Site 808 (Maltman et al., 1993), and IODP Site C0008 (Milliken and Reed, 2010), offer an alternative explanation for the AMS fabric that is widespread in weakly deformed rocks. Milliken and Reed (2010) studied a number of samples of semi-consolidated mud from Nankai (IODP Expedition 316) to determine preferred alignment of platy particles. Using field-emission SEM imaging they observed a number of planar deformation bands, having parallel alignment of both silt and clay-size particles, and the loss of intergranular porosity. Most deformation bands intersect at a high angle to bedding and have a thickness of few to about 200 microns. Such deformation bands do not necessarily involve grain comminution, but they certainly impart a significant small-scale anisotropy that is widespread in the mudrocks.

The AMS properties widely observed in mudrocks from the Nankai accretionary prism are certainly compatible with deformation bands. It is very likely that such planar deformation

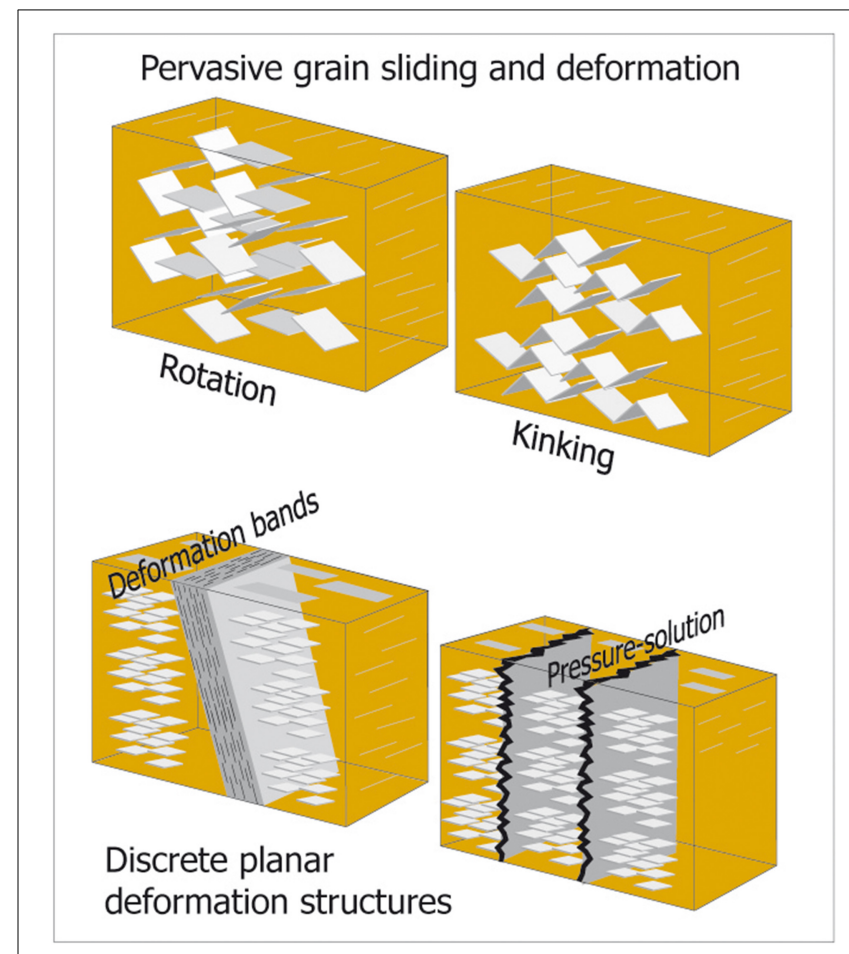

FIGURE 9 | Summary of possible deformation mechanisms that can produce tectonic magnetic fabrics in mudrocks.

structures play a crucial role in determining the AMS in weakly consolidated mud, an aspect that needs to be further explored.

We propose four possible deformation mechanisms that individually or in combination can explain AMS patterns observed in mudrocks from many different tectonic settings (Figure 9). The study of weakly deformed mudrocks using both magnetic and imaging techniques can provide critical validation of these models and advance our understanding of the rock fabric development.

\section{FINAL REMARKS}

Over the past 60 years, AMS data have been shown to be a very sensitive petrofabric tool in mudrocks, with the possibility of becoming a standard method for the quantification of mudrocks fabrics. The main achievements can be summarized as follows:

(1) AMS senses the ductile component of deformation in mudrocks.

(2) Because AMS sense preferred grain orientation (mostly from phyllosilicate grains), grain slippage and rotation must have occurred to develop such tectonic fabric. Both mechanisms sliding and rotation require a reduction in shear strength in order to facilitate the grains to slide past each other. It is thus very likely that sediments were overpressured by an increased fluid pressure. In this regard, because sediments in accretionary prims approach a visco-elastic body, the duration of the applied force (strain rate) has a profound effect on the deformation.

(3) AMS tectonic fabric development predates incipient ("embryonic") cleavage formation, so thus far is possibly 
the most sensitive proxy for elucidating extremely weak deformation.

(4) Whether AMS tectonic fabric is sensing pervasive deformation, localized deformation (e.g., deformation bands) or a combination of mechanisms (Figure 9) is an issue that needs to be further explored.

Overall, there is no doubt that investigations of magnetic fabrics have largely evolved in sixty years, since the seminal study by J. Graham. This review illustrates that AMS is not an "unexploited tool" anymore (Graham, 1954), but certainly an underexploited discipline that is becoming a standard method for the quantification of rock fabrics in deformed mudrocks.

\section{ACKNOWLEDGMENTS}

Most of the ideas summarized in this paper were developed during a sabbatical stay at the Lehigh University. I am very grateful to my colleagues at the Department of Earth and Environmental Sciences for making that stay possible, and for discussions and insights, in particular Dave Anastasio, Ken Kodama, and Frank Pazzaglia. My time was supported by the MECD through the "Salvador de Madariaga Program" (PRX12/00722). I also like to thank the Editor John Geissman, Eric Font, and Dario Bilardello for their comments which helped improving the manuscript.

\section{REFERENCES}

Aubourg, C., Rochette, P., and Vialon, P. (1991). Subtle stretching lineation revealed by magnetic fabric of Callovian-Oxfordian black shales (French Alpes). Tectonophysics 185, 211-223. doi: 10.1016/0040-1951(91)90445-X

Averbuch, O., Frizon de Lamotte, D., and Kissel, C. (1992). Magnetic fabric as a structural indicator of the deformation path within a fold thrust structure: a test case from the Corbieres (NE Pyrenees, France). J. Struct. Geol. 14, 461-474. doi: 10.1016/0191-8141(92)90106-7

Banerjee, S. K., and Stacey, F. D. (1967). "The high-field torque-meter method of measuring magnetic anisotropy in rocks," in Methods in Palaeomagnetism, eds D. W. Collinson, K. M. Creer, and S. K. Runcorn (Amsterdam: Elsevier), 470-476.

Bennett, R., O'Brien, N., and Hulbert, M. (1991). "Determinants of clay and shale microfabric signatures: processes and mechanisms," in Microstructure of FineGrained Sediments: From Mud to Shale, eds R. H. Bennett, W. R. Bryant, and M. H. Hulbert (New York, NY: Springer-Verlag), 5-32.

Biedermann, A. R., Pettke, T., Reusser, E., and Hirt, A. M. (2014). Anisotropy of magnetic susceptibility in natural olivine single crystals. Geochem. Geophys. Geosyst. 15, 3051-3065. doi: 10.1002/2014GC005386

Bilardello, D., and Jackson, M. (2014). A comparative study of magnetic anisotropy measurement techniques in relation to rock-magnetic properties. Tectonophysics 629, 39-54. doi: 10.1016/j.tecto.2014.01.026

Borradaile, G. J. (1988). Magnetic susceptibility, petrofabrics and strain. Tectonophysics 156, 1-20. doi: 10.1016/0040-1951(88)90279-X

Borradaile, G. J., and Gauthier, D. (2001). AMS-detection of inverse fabrics without AARM, in ophiolite dikes. Geophys. Res. Lett. 28, 3517-3520. doi: 10.1029/2001 GL012976

Borradaile, G. J., and Henry, B. (1997). Tectonic applications of magnetic susceptibility and its anisotropy. Earth Sci. Rev. 42, 49-93. doi: 10.1016/S00128252(96)00044-X

Borradaile, G. J., and Jackson, M. (2004). "Anisotropy of magnetic susceptibility (AMS): magnetic petrofabrics of deformed rocks," in Magnetic Fabrics: Methods and Applications, eds F. Martin-Hernandez, C. M. Lüneburg, C. Aubourg, and M. Jackson (London: Geological Society, Special Publications 238), 299-360.

Borradaile, G. J., and Jackson, M. (2010). Structural geology, petrofabrics and magnetic fabrics (AMS, AARM, AIRM). J. Struct. Geol. 32, 1519-1551. doi: 10.1016/j.jsg.2009.09.006
Borradaile, G. J., and Tarling, D. H. (1981). The influence of deformation mechanisms on magnetic fabrics in weakly deformed rocks. Tectonophysics 77, 151-168. doi: 10.1016/0040-1951(81)90165-7

Borradaile, G. J., and Werner, T. (1994). Magnetic anisotropy of some phyllosilicates. Tectonophysics 235, 223-248. doi: 10.1016/0040-1951(94)90196-1

Borradaile, G., Mothersill, J., Tarling, D., and Alford, C. (1986). Sources of magnetic susceptibility in a slate. Earth Planet. Sci. Lett. 76, 336-340. doi: 10.1016/0012821X(86)90084-1

Bouchez, J. L. (1997). "Granite is never isotropic: an introduction to AMS studies of granitic rocks," in Granite - From Segregation of Melt to Emplacement Fabrics, eds J. L. Bouchez, D. H. W. Hutton, and W. E. Stephens (Amsterdam: Kluwer Academic Publishers), 95-112. doi: 10.1007/978-94-017-1717-5_6

Cifelli, F., Mattei, M., Chadima, M., Lenser, S., and Hirt, A. M. (2009). The magnetic fabric in "undeformed clays": AMS and neutron texture analyses from the Rif Chain (Morocco). Tectonophysics 466, 79-88. doi: 10.1016/j.tecto.2008.08.008

Collombat, H., Rochette, P., and Vialon, P. (1995). "Magnetic fabric as a strain indicator in unconsolidated sediments of the Chile Triple Junction area," in Proceedings of the Ocean Drilling Program, Scientific Results, Vol. 141, eds S. D. Lewis, J. H. Behrmann, R. J. Musgrave, and S. C. Cande (College Station, TX: Ocean Drilling Program), 29-49. doi: 10.2973/odp.proc.sr.141.012.1995

Daly, L. (1967). Possibilité d'existence dans les roches de plusieurs anisotropies magnétiques superposes: leur separation. C. R. Acad. Sci. Paris 264, 1377-1380.

Debacker, T. N., Hirt, A. M., Sintubin, M., and Robion, P. (2009). Differences between magnetic and mineral fabrics in low-grade, cleaved siliciclastic pelites: a case study from the Anglo-Brabant Deformation Belt (Belgium). Tectonophysics 466, 32-46. doi: 10.1016/j.tecto.2008.09.039

Debacker, T. N., Robion, P., and Sintubin, M. (2004). "The anisotropy of magnetic susceptibility (AMS) in low-grade, cleaved pelitic rocks: influence of cleavage/bedding angle and type and relative orientation of magnetic carriers," in Magnetic Fabrics: Methods and Applications, eds F. Martin-Hernandez, C. M. Lüneburg, C. Aubourg, and M. Jackson (London: Geological Society, Special Publications 238), 77-107.

de Wall, H., Bestmann,. M., and Ullemeyer, K. (2000). Anisotropy of diamagnetic susceptibility in Thassos marble: a comparison between measured and modeled data. J. Struct. Geol. 22, 1761-1771. doi: 10.1016/S0191-8141(00) 00105-X

Ellwood, B. B. (1978). Measurement of anisotropy of magnetic susceptibility: a comparison of the precision of torque and spinner magnetometer systems of basaltic specimens. J. Phys. E Sci. Instr. 11, 71-75. doi: 10.1088/0022$3735 / 11 / 1 / 017$

Ferré, E. (2002). Theoretical models of intermediate and inverse AMS fabrics. Geophys. Res. Lett. 29, 1127. doi: 10.1029/2001GL014367

Ferré, E. C., Martín-Hernández, F., Teyssier, C., and Jackson, M. (2004). Paramagnetic and ferromagnetic AMS in migmatites: measurements in high and low fields and kinematic implications. Geophys. J. Int. 157, 1119-1129. doi: 10.1111/j.1365-246X.2004.02294.x

Frizon de Lamotte, D., Souqué, C., Grelaud, S., and Robio, P. (2002). Early record of tectonic magnetic fabric during inversión of a sedimentary basin. Short review and examples from the Corbières transfer zone (France). Bull. Soc. Geol. France 173, 461-469. doi: 10.2113/173.5.461

Fuller, M. D. (1960). Anisotropy of susceptibility and the natural remanent magnetization of some Welsh slates. Nature 186, 790-792. doi: 10.1038/186791a0

Fuller, M. D. (1963). Magnetic anisotropy and palaeomagnetism. J. Geophys. Res. 68, 293-309. doi: 10.1029/JZ068i001p00293

Gil-Imaz, A., Pocoví, A., Parés, J. M., and Lago, M. (2000). Effect of lithostatic pressure and tectonic deformation on the magnetic fabric (anisotropy of magnetic susceptibility) in low-grade metamorphic rocks. J. Geophys. Res. 105, 21305-21317. doi: 10.1029/2000JB900171

Girdler, R. W. (1961). The measurement and computation of anisotropy of magnetic susceptibility in rocks. Geophys. J. R. Astron. Soc. 5, 34-44. doi: 10.1111/j.1365-246X.1961.tb02927.x

Goswami, T. K., and Sarmah, R. K. (2013). Conditions of compaction and development of diagenetic microstructures in the Dafla and Subansiri sandstones, Western Arunachal Pradesh, India. Eur. Sci. J. 12, 309-320.

Graham, J. W. (1954). Magnetic susceptibility anisotropy, an unexploited petrofabric element. Geol. Soc. Am. Bull. 65, 1257-1258.

Graham, J. W. (1966). "Significance of magnetic Anisotropy in Appalachian Sedimentary rocks," in The Earth Beneath the Continents. Geophysical 
Monograph Series 10, eds S. Steinhart and T. J. Smith (Washington, DC: American Geophysical Union), 627-648.

Granar, L. (1958). Magnetic measurements on Swedish varved sediments. Arkivfor Geofysik 3, 1-40.

Hamilton, N., and Rees, A. I. (1971). The anisotropy of magnetic susceptibility of the Franciscan rocks of the Diablo Range, Central California. Geol. Rundsch. 60 , 1103-1124. doi: 10.1007/BF02046538

Heller, F. (1973). Magnetic anisotropy of granitic rocks of the Bergell massif (Switzerland). Earth Planet. Sci. Lett. 20, 180-188. doi: 10.1016/0012821X(73)90156-8

Henry, B. (1983). Interpre'tation quantitative de l'anisotropie de susceptibilite magnétique. Tectonophysics 91, 165-177. doi: 10.1016/0040-1951(83)90064-1

Henry, B. (1997). The magnetic zone axis: a new element of magnetic fabric for the interpretation of the magnetic lineation. Tectonophysics 271, 325-331. doi 10.1016/S0040-1951(96)00267-3

Henry, B., and Daly, L. (1983). From qualitative to quantitative magnetic anisotropy analysis: the prospect of finite strain calibration. Tectonophysics 98, 327-336. doi: 10.1016/0040-1951(83)90300-1

Hirt, A.; Lowrie, W., Clendenen, W. S., and Kligfield, R. (1988). The correlation of magnetic anisotropy with strain in the Chelmsford Formation of the Sudbury Basin, Ontario. Tectonophysics 145, 177-189. doi: 10.1016/0040-1951(88) 90194-1

Hirt, A. M., Evans, K. F., and Engelder, T. (1995). Correlation between magnetic anisotropy and fabric for Devonian shales on the Appalachian Plateau. Tectonophysics 247, 121-132. doi: 10.1016/0040-1951(94)00176-A

Hirt, A. M., and Gehring, A. U. (1991). Thermal alteration of the magnetic mineralogy in ferruginous rocks. J. Geophys. Res. 96, 9947-9953. doi 10.1029/91JB00573

Hirt, A. M., Julivert, M., and Soldevila, J. (2000). Magnetic fabric and deformation in the Navia-Alto Sil slate belt, northwestern Spain. Tectonophysics 320, 1-16.

Hirt, A. M., Lowrie, W., Lüneburg, C., Lebit, H., and Engelder, T. (2004). "Magnetic and mineral fabric development in the Ordovician Martinsburg Formation in the Central Appalachian Fold and Thrust Belt, Pennsylvania," in Magnetic Fabrics: Methods and Applications, eds F. Martin-Hernandez, C. M. Lüneburg, C. Aubourg, and M. Jackson (London: Geological Society, Special Publications 238), 109-126.

Hounslow, M. W. (1990). "Grain fabric measured using magnetic susceptibility anisotropy in deformed sediments of the Barbados accretionary prism: Leg 110," in Proceedings of the Ocean Drilling Program, Scientific Results, Vol. 1001, (College Station, TX: Ocean Drilling Program), 257-275. doi: 10.2973/odp.proc.sr.110.156.1990

Hounslow, M. W. (2001). The crystallographic fabric and texture of sidertite in concretions: implications for siderite nucleation and growth processes. Sedimentology 48, 533-557. doi: 10.1046/j.1365-3091.2001.00375.x

Housen, B. A., Tobin, H. J., Labaume, P., Leitch, E. C., Maltman, A. J., and ODP Leg 156 Shipboard Science Party. (1996). Strain decoupling across the decollement of the Barbados accretionary prism. Geology 24, 127-130.

Housen, B. A. (1997). "Magnetic anisotropy of Barbados prism sediments," in Proceedings of the Ocean Drilling Program, Scientific Results, Vol. 156, eds T. H. Shipley, Y. Ogawa, P. Blum, and J. M. Bahr (College Station, TX: Ocean Drilling Program), 97-105.

Housen, B. A., Richter, C., and van der Pluijm, B. A. (1993). Composite magnetic anisotropy fabrics: experiments, numerical models, and implications for the quantification of rock fabrics. Tectonophysics 220, 1-12. doi: 10.1016/00401951(93)90219-A

Housen, B. A., and Sato, T. (1995). "Magnetic anisotropy fabrics from the Cascadia accretionary prism," in Proceedings of the Ocean Drilling Program, Scientific Results, Vol. 146 (College Station, TX: Texas A\&M University), 233-254.

Hrouda, F., and Janak, F. (1976). The changes in shape of the magnetic susceptibility ellipsoid during progressive metamorphism and deformation. Tectonophysics 34, 135-148. doi: 10.1016/0040-1951(76)90181-5

Hrouda, F., and Jelimek, V. (1990). Resolution of ferrimagnetic and paramagnetic anisotropies in rocks, using combined low-field and high-field measurements. Geophys. J. Int. 103, 75-84. doi: 10.1111/j.1365-246X.1990.tb01753.x

Ihmlé, P. F., Hirt, A. M., Lowrie, W., and Dietrich, D. (1989). Inverse magnetic fabric in deformed limestones of the Morcles Nappe, Switzerland. Geophys. Res. Lett. 16, 1383-1386. doi: 10.1029/GL016i012p01383
Ising, G. (1942). On the magnetic properties of varved clay. Ark. Mat. Astron. Fys. 29a, 1-37.

Jackson, M. (1991). Anisotropy of magnetic remanence: a brief review of mineralogical sources, physical origins, and geological applications, and comparison with susceptibility anisotropy. Pure Appl. Geophys. 136, 1-28. doi: 10.1007/BF00878885

Jelinek, V. (1973). Precision A.C. bridge set for measuring magnetic susceptibility of rocks and its anisotropy. Studia Geophysica Geodetica 17, 36-48. doi: 10.1007/ BF01614027

Kanamatsu, T., and Matsuo, K. (2003). "Rock magnetic study of sediments from the Japan Trench, ODP Leg 186: implications for deformation of sediments," in Proceedings of the Ocean Drilling Program, Scientific Results, Vol. 186, eds K. Suyehiro, I. S. Sacks, G. D. Acton, and M. Oda (College Station, TX: Ocean Drilling Program), 1-21. doi: 10.2973/odp.proc.sr.186.113.2003

Kanamatsu, T., Parés, J. M., and Kitamura, Y. (2012). Pliocene shortening direction of Nankai Trough off Kumano southwest Japan, Sites IODP C0001 and C0002, Expedition 315, anisotropy of magnetic susceptibility analysis for paleostress. Geochem. Geophys. Geosyst. 13, Q0AD22. doi: 10.1029/2011GC003782

Kanaori, Y., Kawakami, S., and Yairi, K. (1991). Microstructure of deformed biotite defining foliation in cataclastic zones in granite, central Japan. J. Struct. Geol. 13, 777-786. doi: 10.1016/0191-8141(91)90003-2

Kawamura, K., and Ogawa, Y. (2002). "Progressive microfabric changes in unconsolidated pelagic and hemipelagic sediments down to $180 \mathrm{mbsf}$, northwest Pacific, ODP Leg 185, Site 1149," in Proceedings of the Ocean Drilling Program, Scientific Results, Vol. 185, eds J. N.Ludden, T. Plank, and C. Escutia (College Station, TX: Ocean Drilling Program), 1-29, doi: 10.2973/odp.proc.sr.185.003.2002

Kawamura, K., and Ogawa, Y. (2004). Progressive change of pelagic clay microstructure during burial process: examples from piston cores and ODP cores. Mar. Geol. 207, 131-144. doi: 10.1016/j.margeo.2004.03.016

Kelso, P. R., Tikoef, B., Jackson, M., and Sun, W. (2002). A new method for the separation of paramagnetic and ferromagentic susceptibility anisotropy using low field and high field methods. Geophys. J. Int. 151, 345-359. doi: 10.1046/j.1365-246X.2002.01732.x

Kent, D. V., and Lowrie, W. (1975). On the magnetic susceptibility anisotropy of deep-sea sediment. Earth Planet. Sci. Lett. 28, 1-12. doi: 10.1016/0012$821 X(75) 90067-9$

Khan, M. A. (1962). Anisotropy of magnetic susceptibility of some igneous and metamorphic rocks. J. Geophys. Res. 67, 2873-2885. doi: 10.1029/JZ067i0 $07 \mathrm{p} 02873$

King, R. F. (1966). The magnetic fabric of some Irish granites. Geol. J. 5, 43-46. doi: 10.1002/gj.3350050106

Kissel, C., Barrier, E., Laj, C., and Lee, T. Q. (1986). Magnetic fabric in 'undeformed' marine clays from compressional zones. Tectonics 5, 769-781. doi: 10.1029/TC005i005p00769

Kligfield, R., Lowrie, W., and Dalziel, I. W. D. (1977). Magnetic susceptibility anisotropy as a strain indicator in the Sudbury basin, Ontario. Tectonophysics 40, 287-308. doi: 10.1016/0040-1951(77)90070-1

Kligfield, R., Owens, W. H., and Lowrie, W. (1981). Magnetic susceptibility anisotropy, strain and progressive deformation in Permian sediments from the Maritime Alps (France). Earth Planet. Sci. Lett. 55, 181-189. doi: 10.1016/0012821X(81)90097-2

Kodama, K. P., and Sun, W. W. (1992). Magnetic anisotropy as a correction for compaction-caused paleomagnetic inclination shallowing. Geophys. J. Int. 111, 465-469. doi: 10.1111/j.1365-246X.1992.tb02104.x

Kopf, A., and Berhman, J. H. (1997). Fabric evolution and mechanisms of diagenesis in fine-grained sediments from the Kita-Yamato Trough, Japan Sea. J. Sediment. Res. 67, 590-600.

Lamarche, G., and Rochette, P. (1987). La fabrique magnrtique du Flysch Dauphinois (Alpes Françaises): origine et application quantitative. Geodyn. Acta $1,101-111$.

Langston, R. B., and Pask, J. A. (1958). Analysis of consistencies of kaolin-water systems below the plastic range. Clays Clay Miner. 566, 4-28.

Larrasoaña, J. C., Pueyo, E. L., and Parés, J. M. (2004). "An integrated AMS, structural, palaeo- and rockmagnetic study of the Eocene marine marls from the Jaca-Pamplona basin (Pyrenees, N Spain): new insights into the timing of magnetic fabric acquisition in weakly deformed mudrocks," in Magnetic Fabrics: Methods and Applications, eds F. Martin-Hernandez, C. M. Lüneburg, 
C. Aubourg, and M. Jackson (London: Geological Society, Special Publications 238), 127-144

Lowrie, W. (1989). "Magnetic analysis of rock fabric," in The Encyclopedia of Solid Earth Geophysics, ed D. E. James (New York, NY: Van Nostrand Reinhold), 698-706.

Lundberg, N., and Karig, D. E. (1986). "Structural features from the Nankai Trough lower slope, Deep Sea Drilling Project Sites 582 and 583," in Initial Reports of the Deep Sea Drilling Project, eds H. Kagami, D. E. Karig, W. T. Coulbourn, et al. (Washington, DC), 87, 797-808. doi: 10.2973/dsdp.proc.87.126.1986

Lüneburg, C. M., Lampert, S. A., Lebit, H. D., Hirt, A. M., Casey, M., and Lowrie, W. (1999). Magnetic anisotropy, rock fabrics and finite strain in deformed sediments of SW Sardinia (Italy). Tectonophysics 307, 51-74. doi: 10.1016/S0040-1951(99)00118-3

Maltman, A. (1994). The Geological Deformation of Sediments. Cambridge: Chapman \& Hall. doi: 10.1007/978-94-011-0731-0

Maltman, A. J., Byrne, T., Karig, D. E., Lallemant, S., Knipe, R., and Prior, D. (1993). "Deformation structures at Site 808, Nankai accretionary prism, Japan," in Proceedings of the Ocean Drilling Program, Scientific Results, Vol. 131, eds I. A. Hill, A. Taira, J. V. Firth, et al. (College Station, TX: Ocean Drilling Program), 123-133. doi: 10.2973/odp.proc.sr.131.110.1993

Martín-Fernández, F., and Ferré, E. (2007). Separation of paramagnetic and ferromagnetic anisotropies: a review. J. Geophys. Res. 112, B03105. doi: 10.1029/2006JB004340

Martín-Hernández, F., and Hirt, A. M. (2001). Separation of ferrimagnetic and paramagnetic anisotropies using a high-field torsion magnetometer. Tectonophysics 337, 209-221. doi: 10.1016/S0040-1951(01)00116-0

Martín-Hernández, F., and Hirt, A. M. (2003). The anisotropy of magnetic susceptibility in biotite, muscovite and chlorite single crystals. Tectonophysics 367 , 13-28. doi: 10.1016/S0040-1951(03)00127-6

Martín-Hernández, F., Lüneburg, C. M., Aubourg, C. and Jackson, M. (eds.). (2004). "Magnetic fabric: methods and applications-an introduction," in Magnetic Fabric: Methods and Applications, Vol. 238 (Geological Society, London: Special Publications), 1-7. doi: 10.1144/GSL.SP.2004.238.01.01

Milliken, K. L., and Reed, R. M. (2010). Multiple causes of diagenetic fabric anisotropy in weakly consolidated mud, Nankai accretionary prism, IODP Expedition 316. J. Struct. Geol. 32, 187-1898. doi: 10.1016/j.jsg.2010.03.008

Mochales, T., Pueyo, E. L., Casas, A. M., Barnolas, A., and Oliva-Urcia, B. (2010). Anisotropic magnetic susceptibility record of the kinematics of the Boltaña Anticline (Southern Pyrenees). Geol. J. 45, 562-581. doi: 10.1002/gj.1207

Molyneux, L. (1971). A complete result magnetometer for measuring the remnant magnetization of rocks. Geophys. J. 24, 429-433. doi: 10.1111/j.1365246X.1971.tb02188.x

Moon, C. F., and Hurst, C. W. (1984). "Fabrics of muds and shales: an overview," in Fine-Grained Sediments: Deep-Water Processes and Facies, Vol. 15, eds D. A. V. Stow and D. J. W. Piper (London: Geological Society, Special Publications), 579-593. doi: 10.1144/GSL.SP.1984.015.01.36

Moore, G. F., Park, J.-O., Bangs, N. L., Gulick, S. P., Tobin, H. J., Nakamura, Y., et al. (2009). "Structural and seismic stratigraphic framework of the NanTroSEIZE Stage 1 transect," in Expedition 314/315/316 Scientists, Proc. IODP, 314/315/316, eds M. Kinoshita, H. Tobin, J. Ashi, G. Kimura, S. Lallemant, E. J. Screaton, D. Curewitz, H. Masago, and K. T. Moe (Washington, DC: Integrated Ocean Drilling Program Management International, Inc.). doi: 10.2204/iodp.proc. 314315316.102.2009

Moore, G. F., Taira, A., Klaus, A., Becker, L., Boeckel, B., Cragg, B. A., et al. (2001). New insights into deformation and fluid flow processes in the Nankai Trough accretionary prism: results of Ocean Drilling Program Leg 190. Geochem. Geophys. Geosyst. 2:1058. doi: 10.1029/2001GC000166

Novak, B., Housen, B., Kitamura, Y., Kanamatsu, T., and Kawamura, K. (2014). Magnetic fabric analyses as a method for determining sediment transport and deposition in deep sea sediments. Mar. Geol. 356, 19-30. doi: 10.1016/j.margeo. 2013.12.001

Nye, J. F. (1957). The Physical Properties of Crystals. Oxford: Clarendon Press.

Oliva, B., Larrasoaña, J. C., Pueyo, E. L., Gil-Imaz, A., Mata, P., Parés, J. M., et al. (2009). Disentangling magnetic subfabrics and their link to deformation processes in cleaved sedimentary rocks from the Internal Sierras (west central Pyrenees, Spain). J. Struct. Geol. 31, 163-176. doi: 10.1016/j.jsg.2008. 11.002

Owens, W. (1993). "Magnetic fabric studies of samples from Hole 808C, Nankai Trough," in Proceedings of the Ocean Drilling Program, Scientific Results, Vol. 131, eds I. A. Hill, A. Taira, J. V. Firth et al. (College Station, TX: Ocean Drilling Program), 301-310. doi: 10.2973/odp.proc.sr.131.130.1993

Owens, W. H. (1995). "Data report: anisotropy of magnetic susceptibility of a set of samples from the Cascadia margin," in Proceedings of the Ocean Drilling Program, Scientific Results, Vol. 146 (Pt. 1), eds B. Carson, G. K. Westbrook, R. J. Musgrave, and E. Suess (College Station, TX: Ocean Drilling Program), 451-453. doi: 10.2973/odp.proc.sr.146-1.252.1995

Owens, W. H., and Bamford, D. (1976). Magnetic, seismic and other anisotropic properties of rock fabric. Philos. Trans. R. Soc. Lond. A 283, 55-68. doi: 10.1098/ rsta.1976.0069

Parés, J. M. (2004). "How deformed are weakly deformed rocks? Insights from magnetic anisotropy," in Magnetic Fabrics: Methods and Applications, eds F. Martin-Hernandez, C. M. Lüneburg, C. Aubourg, and M. Jackson (London: Geological Society, Special Publications 238), 191-203.

Parés, J. M., and Dinarès, J. (1993). Magnetic fabric in two sedimentary rock types from the Southern Pyrenees. J. Geomagn. Geoelectr. 45, 193-205. doi: 10.5636/jgg.45.193

Parés, J. M., and van der Pluijm, B. A. (2002). Evaluating magnetic lineations (AMS) in deformed rocks. Tectonophysics 350, 283-298. doi: 10.1016/S00401951(02)00119-1

Parés, J. M., and van der Pluijm, B. A. (2003). Magnetic fabrics in low-strain mudrocks: AMS of pencil structures in the Knobs Formation, Valley and Ridge Province, US Appalachians. J. Struct. Geol. 5, 1349-1358. doi: 10.1016/S01918141(02)00197-9

Parés, J. M., van der Pluijm, B., and Dinares-Turell, J. (1999). Evolution of magnetic fabrics during incipient deformation of mudrocks (Pyrenees, northern Spain). Tectonophysics 307, 1-14. doi: 10.1016/S0040-1951(99) 00115-8

Parma, J. (1988). An automated torque meter for rapid measurement of high field magnetic anisotropy of rocks. Phys. Earth Planet. Inter. 51, 387-389. doi: 10.1016/0031-9201(88)90080-5

Parry, G. R. (1971). The Magnetic Anisotropy of Some Deformed Rocks. Unpublished Ph.D. thesis, University of Birmingham.

Pueyo-Anchuela, O., Pocoví A., and Gil Imaz, A. (2010). Tectonic imprint in magnetic fabrics in foreland basins: a case study from the Ebro Basin, N Spain. Tectonophysics 492, 150-163. doi: 10.1016/j.tecto.2010.06.016

Ramsay, J. G., and Huber, M. I. (1983). The Techniques of Modern Structural Geology, Volume 1: Strain Analysis. London: Academic Press.

Rathore, J. S. (1975). Studies of Magnetic Susceptibility Anisotropy in Rocks. Ph.D. thesis (unpublished), Newcastle Upon Tyne.

Rathore, J. S. (1980). The magnetic fabric of some slates from the Borrowdale Volcanic Group in the English Lake District and their correlations with strain. Tectonophysics 67, 207-220. doi: 10.1016/0040-1951(80) 90235-8

Rees, A. I. (1961). The effect of water currents on the magnetic remanence and anisotropy of susceptibility of some sediments. Geophys. J. R. Astron. Soc. 5, 235-251. doi: 10.1111/j.1365-246X.1961.tb00431.x

Rees, A. I. (1965). The use of anisotropy of magnetic susceptibility in the estimation of sedimentary fabric. Sedimentology 4, 257-271. doi: 10.1111/j.13653091.1965.tb01550.x

Richter, C., van der Pluijm, B., and Housen, B. (1993). The quantification of crystallographic preferred orientation using magnetic anisotropy. J. Struct. Geol. 15, 113-116. doi: 10.1016/0191-8141(93)90082-L

Robion, P., Averbuch, O., and Sintubin, M. (1999). Fabric development and metamorphic evolution of lower Palaeozoic slaty rocks from the Rocroi massif (French-Belgian Ardennes): new constraints from magnetic fabrics, phyllosilicate preferred orientation and illite crystallinity data. Tectonophysics 309, 257-273. doi: 10.1016/S0040-1951(99)00142-0

Robion, P., Frizon de Lamotte, D., Kissel, C., and Aubourg, C. (1995). Tectonic versus mineralogical contribution to the magnetic fabrics of epimetamorphic slaty rocks: an example from the Ardennes Massif (France-Belgium). J. Struct. Geol. 17, 1111-1124. doi: 10.1016/0191-8141(95)00002-U

Robion, P., Kissel, C., Frizon de Lamotte, D., Lorand, J. P., and Guézou, J. C. (1997). Magnetic mineralogy and metamorphic zonation in the Ardennes Massif (France-Belgium). Tectonophysics 271, 231-248. doi: 10.1016/S00401951(96)00268-5

Robion, R., Grelaud, S., and Frizon de Lamotte, D. (2007). Prefolding magnetic fabrics in fold-and-thrust belts: why the apparent internal deformation of the sedimentary rocks from the Minervois basin (NE-Pyrenees, France) is so high 
compared to the Potwar basin (SW-Himalaya). Sed. Geol. 196, 181-200. doi: 10.1016/j.sedgeo.2006.08.007

Rochette, P., and Fillion, G. (1988). Identification of multicomponent anisotropies in rocks using various field and temperature values in a cryogenic magnetometer. Phys. Earth Planet. Inter. 51, 379-386. doi: 10.1016/0031-9201(88)90079-9

Rochette, P., and Vialon, P. (1984). Development of planar and linear fabrics in Dauphinois shales and slates (French Alps) studied by magnetic anisotropy and its mineralogical control. J. Struct. Geol. 6, 33-38. doi: 10.1016/01918141(84)90081-6

Sagnotti, L., and Speranza, S. (1993). Magnetic fabrics analysis of the PlioPleistocene clayey units of the Sant'Arcangelo basin, Southern Italy. Phys. Earth Planet. Inter. 77, 165-176. doi: 10.1016/0031-9201(93)90096-R

Sagnotti, L., Winkler, A., Montone, P., Di Bella, L. D., Florindo, F., Mariucci, M. T., et al. (1999). Magnetic anisotropy of Plio-Pleistocene sediments from the Adriatic margin of the northern Apennines (Italy): implications for the time-space evolution of the stress field. Tectonophysics 311, 139-153. doi: 10.1016/S0040-1951(99)00159-6

Saint-Bezar, B., Hebert, R. L., Aubourg, C., Robion, P., Swennen, R., and Frizon de Lamotte, D. (2002). Magnetic fabric and petrografic investigation of hematitebearing sandstones within ramp-related folds: examples from the Southern Atlas Front (Morocco). J. Struct. Geol. 24, 1507-1150. doi: 10.1016/S01918141(01)00140-7

Sans, M., Vergés, J., Gomis, E., Parés, J. M., Schiattarella, M. A., Travé, F., et al. (2003). Layer parallel shortening in salt-detached folds: constraint on cross-section restoration. Tectonophysics 372, 85-104. doi: 10.1016/S00401951(03)00233-6

Schmidt, V., Hirt, A. M., Leiss, B., Burlini, L., and Walter, J. (2009). Quantitative correlation of strain, texture and magnetic anisotropy of compacted calcite-muscovite aggregates. J. Struc. Geol. 31, 1062-1073. doi: 10.1016/j.jsg.2008.11.012

Schmidt, V. A., Ellwood, B. B., Nagata, T., and Noltimier, H. C. (1988). The measurement of anisotropy of magnetic susceptibility using a cryogenic (SQUID) magnetometer and a comparison with results obtained from a torsion-fiber magnetometer. Phys. Earth Planet. Inter. 51, 365-378. doi: 10.1016/00319201(88)90078-7

Schneider, J. L., Chagué-Goff, C., Bouchez, J. L., Goff, J., Sugawara, D., Goto, K., et al. (2014). Using magnetic fabric to reconstruct the dynamics of tsunami deposition on the Sendai Plain, Japan - The 2011 Tohoku-oki tsunami. Mar. Geol. 358, 89-106. doi: 10.1016/j.margeo.2014.06.010

Schwehr, K., Tauxe, L., Driscoll, N., and Lee, H. (2006). Detecting compaction disequilibrium with anisotropy of magnetic susceptibility. Geochem. Geophys. Geosyst. 7, Q11002. doi: 10.1029/2006GC001378

Scriba, H., and Heller, F. (1978). Measurements of anisotropy of magnetic susceptibility using inductive magnetometers. J. Geophys. 44, 341-352.

Soto, R., Larrasoaña, J. C., Arlegui, L. E., Beamud, E., Oliva-Urcia, B., and Simón, J. L. (2009). Reliability of magnetic fabrics of weakly deformed mudrocks as a palaeostress indicator in compressive settings. J. Struct. Geol. 31, 512-522. doi: 10.1016/j.jsg.2009.03.006

Souqué, C., Robion, P., and Frizon de Lamotte, D. (2002). Cryptic magnetic fabric of tectonic origin revealed by heating of sedimentary samples from the Corbières, France. Phys. Chem. Earth 27, 1253-1262. doi: 10.1016/S14747065(02)00111-0

Stephenson, M., Sadikun, S., and Potter, D. K. (1986). A Theoretical and experimental comparison of the anisotropies of magnetic susceptibility and remanence in rocks and minerals. Geophys. J. R. Astron. Soc. 84, 185-200. doi: 10.1111/j.1365-246X.1986.tb04351.x

Stesky, R. M. (1978). Mechanisms of high temperature frictional sliding in Westerly granite. Can. J. Earth Sci. 15, 361-375. doi: 10.1139/e78-042

Taira, A., and Niitsuma, N. (1986). "Turbidite sedimentation in the Nankai Trough as interpreted from magnetic fabric, grain size, and detrital modal analyses," in Initial Reports of the Deep Sea Drilling Project, Vol. 87 (Washington DC: U.S. Government Printing Office), 611-632.
Tarling, D. H., and Hrouda, F. (1993). The Magnetic Anisotropy of Rocks. London: Chapman and Hall.

Thill, J. W., Ferre, E. C., Rainey, E. S. G., and Teyssier, C. (2000). Separation of AMS into ferrimagnetic and paramagnetic components in migmatites: a possible shear-sense indicator? EOS Trans. Am. Geophys. Union $81,367$.

Turner, G. M., and Gough, D. I. (1983). Magnetic fabric, strain and paleostress in the Canadian Rocky Mountains. Tectonophysics 96, 311-330. doi: 10.1016/00401951(83)90224-X

Ujiie, K., Hisamitsu, T., Maltman, A. J., Morgan, J. K., Sánchez-Gómez, M., and Tobin, H. J. (2003a). "Deformation structures and magnetic fabrics at Site 1178: implication for deformation history recorded in accreted sediments at an evolved portion of the Nankai accretionary prism," in Proceedings of the Ocean Drilling Program, Scientific Results, Vol. 190/196, eds H. Mikada, G. F. Moore, A. Taira, K. Becker, J. C. Moore, and A. Klaus (College Station, TX: Ocean Drilling Program), 1-15. doi: 10.2973/odp.proc.sr.190196. 202.2003

Ujiie, K., Hisamitsu, T., and Taira, A. (2003b). Deformation and fluid pressure variation during initiation and evolution of the plate boundary décollement zone in the Nankai Accretionary Prism. J. Geophys. Res. 108:2398. doi: 10.1029/2002JB002314

Van der Pluijm, B., and Kaars-Sijpesteijn, C. H. (1984). Chlorite-mica aggregates: morphology, orientation, development and bearing on cleavage formation in very-low-grade rocks. J. Struct. Geol. 4, 309-407. doi: 10.1016/01918141(84)90040-3

Wassmer, P., Schneider, J. L., Fonfrege, A. V., Lavigne, F., Paris, R., and Gomez, C. (2010). Use of anisotropy of magnetic susceptibility (AMS) in the study of tsunami deposits: application to the 2004 deposits on the eastern coast of Banda Aceh, North Sumatra, Indonesia. Mar. Geol. 275, 255-272. doi: 10.1016/j.margeo.2010.06.007

Weil, A. B., and Yonkee, A. (2009). Anisotropy of magnetic susceptibility in weakly deformed red beds from the Wyoming salient, Sevier thrust belt: relations to layer-parallel shortening and orogenic curvature. Lithosphere 1, 235-256. doi: $10.1130 / \mathrm{L} 42.1$

Wilson, M. J., and Wilson, L. (2014). Clay mineralogy and shale instability: an alternative conceptual analysis. Clay Minerals 49, 127-145. doi: 10.1180/claymin.2014.049.2.01

Zhang, S., Cañon Tapia, E., and Walderhaug, H. J. (2011). Magnetic fabric and its significance in the sills and lava flows from Taimyr foldbelt, Arctic Siberia. Tectonophysics 505, 68-85. doi: 10.1016/j.tecto.2011. 04.004

Zhu, Z., Zhang, S., Tang, C., Li, H., Xie, S., Ji, J., et al. (2012). Magnetic fabric of stalagmites and its formation mechanism. Geochem. Geophys. Geosyst. 13, Q06006. doi: 10.1029/2011GC003869

Conflict of Interest Statement: The author declares that the research was conducted in the absence of any commercial or financial relationships that could be construed as a potential conflict of interest.

Received: 30 October 2014; accepted: 28 January 2015; published online: 17 February 2015.

Citation: Parés JM (2015) Sixty years of anisotropy of magnetic susceptibility in deformed sedimentary rocks. Front. Earth Sci. 3:4. doi: 10.3389/feart.2015.00004

This article was submitted to Geomagnetism and Paleomagnetism, a section of the journal Frontiers in Earth Science.

Copyright (1) 2015 Parés. This is an open-access article distributed under the terms of the Creative Commons Attribution License (CCBY). The use, distribution or reproduction in other forums is permitted, provided the original author(s) or licensor are credited and that the original publication in this journal is cited, in accordance with accepted academic practice. No use, distribution or reproduction is permitted which does not comply with these terms. 